\title{
Ruling brings cash windfall in US fraud case
}

San Diego. In a novel lawsuit, a New York scientist last week won a $\$ 1.9$ million-judgement against a group of Alabama researchers who were found by a jury to have stolen study results and used them to improperly obtain federal grants.

The lawsuit, which was heard in federal court in Baltimore, Maryland, is thought to be the first case in the United States where a jury has ruled that academic scientists stole research results from another scientist.

In last week's case, Pamela A. Berge, an epidemiologist, successfully sued three paediatricians and a junior researcher at the University of Alabama at Birmingham for stealing her work and presenting it to the National Institutes of Health (NIH) as their own. The paediatricians, all physicians, are Robert Pass, Sergio Stagno and Charles Alford. The junior researcher, Karen B. Fowler, is now an assistant professor.

On 1 May, a federal jury in Baltimore found in Berge's favour. And on 16 May, US District Judge Edward S. Northrop ordered the University of Alabama to pay $\$ 1.66$ million for making false claims to the NIH. The US government will receive $\$ 1,162,000$ and Berge will receive the remaining $\$ 498,000$, as well as an additional $\$ 265,000$ from the Alabama scientists for misappropriation of her research, of which $\$ 215,000$ is punitive damages. The University of Alabama has also been ordered to pay a $\$ 10,000$ fine in addition to Berge's legal costs.

The Alabama physicians are renowned for their 17 years of work on cytomegalovirus (CMV), a genital viral infection that can cause eye, ear or neurological impairment in newborn infants. They were laying the groundwork for a vaccine to prevent mother-to-child infection with the virus. The NIH continues to provide about $\$ 1$ million annually to the Alabama research team. $\mathrm{NIH}$ officials say they are assessing the legal case to determine what, if any, action they should take.

Neither the Alabama researchers - who denied any impropriety in documents submitted to the court - nor their attorneys would discuss the verdict. But the university's general counsel, Ina Leonard, issued a brief statement on 18 May saying the university "is extremely disappointed about the jury verdict". Leonard said those convicted intend to appeal. "We believe the verdict is wrong and that it is not consistent with or supported by the evidence presented."

For Berge, now 47 and a consultant at Pfizer Inc., the entire affair remains baffling. "It has been a nightmare," she said. Berge, who has since lost her academic job, says she now feels smeared for having challenged her collaborators. "I am appalled at what happened. I don't understand the motive. I don't understand why it had to happen."

Berge was a doctoral student at Cornell
University in New York in 1987, and spent nearly a year in Alabama, collaborating with the Birmingham group. She had alleged that the Alabama team gave data from her research to Fowler, then a doctoral student. She accused Fowler of plagiarizing her work, misusing her methodology and then using the research for her 1990 dissertation and two articles published in 1991 and 1993.

Berge also alleged that the Alabama team repeatedly over several years made false representations to win continuing grants from the NIH. The Alabama team, she claimed, misrepresented the status of the project to the NIH, omitted results that contradicted its theories, and claimed Berge's work as their own.

The case was tried under the so-called 'whistle-blower law', a federal statute that allows those who expose fraud in government to receive a share of any money recovered in subsequent litigation.

The law was enacted primarily to combat fraud in the defence industry, but it has recently been used in a number of cases to expose the misuse of grants from the
National Institutes of Health (NIH).

According to several government and legal authorities, Berge's lawsuit is the first case under the whistle-blower law involving allegations of scientific misconduct that was decided by jury. (The other cases were dismissed or settled by out-of-court payments.)

US researchers are increasingly turning to the courts to resolve disputes that have historically been addressed in academic institutions $-\mathrm{a}$ trend that is already producing considerable debate over methods for handling scientific misconduct cases.

Those who advocate use of the courts to decide such scientific disputes say universities and government funding agencies have failed to handle complaints of wrongdoing fairly and effectively. One result is that academic reviews can drag on for years, damaging the careers of both the accuser and the accused.

But others say the courts are the wrong place to adjudicate such disputes, as the outcome is more likely to depend on the skill of attorneys and knowledge of legal procedures than on factual evidence. Rex Dalton

\section{Costs discourage European patents}

Munich. High administrative fees and translation costs are discouraging small and medium-sized firms in Europe from filing patents, according to the results of a survey published last week by the European Patent Office in Munich (EPO).

The EPO commissioned the survey following continued complaints from industry that the costs of patenting through the EPO were higher than either through national patent offices in Europe, or through the United States Patent and Trademark Office (USPTO) and the Japanese Patent Office (JPO).

In recent years, European firms have been filing increasingly fewer patent applications - although the number last year was slightly higher than in 1993 - particularly in key technologies, where most patents are now owned by non-European companies (see chart).

The EPO is keen to identify ways of changing this situation by reducing the costs of patenting. But the true costs have been difficult to estimate, as they are shared between the applicants, patent offices and patent attorneys. It is also difficult to make international comparisons, as the level of patent protection is not identical in each country.

Companies with their own patent departments, national patent offices and patent attorneys were asked by the EPO to estimate their expenses during 1992. The results show that the true total cost of an average EPO patent, including translation costs and official fees, amounts to DM45,510 (US\$32,500) for registration in the eight most designated member states.

This price does not include the annual

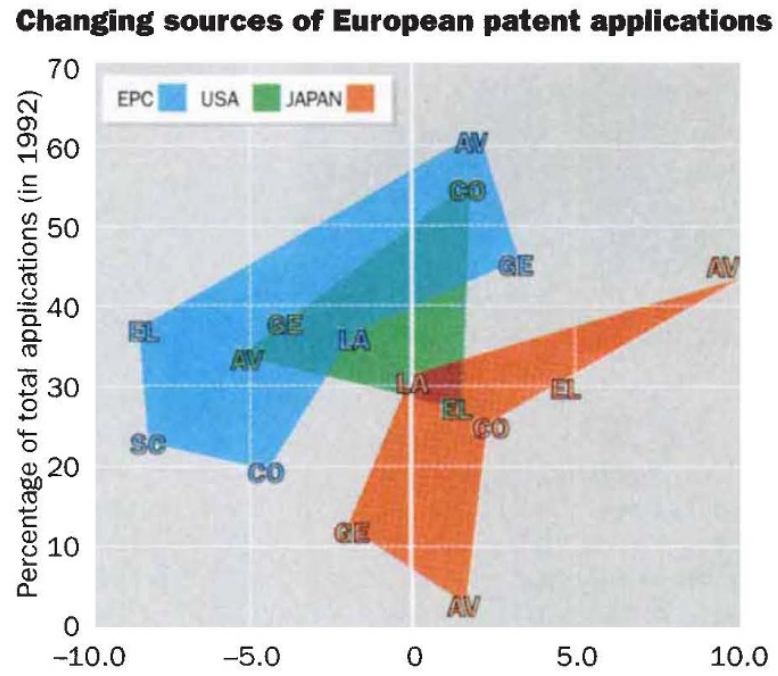

Increase/decrease of the percentage of total applications compared with 1986

CO-Computing SC-Semiconductors LA-Laser AV-Aviation GE-Genetic engineering EL-Electronics/communications 
renewal fees which the applicant must pay to the national patent offices in the designated countries to keep the patent alive (half of these fees are returned to the EPO).

The survey concludes that it is still cheap$\mathrm{er}$, as intended in the European Patent Convention of 1973 , for a company to patent an invention through the EPO, designating protection in the three largest member countries - namely the United Kingdom, Germany and France - than filing individually in the three countries. This is primarily because only one set of attorney fees is involved, instead of three. But the margin is only six per cent.

The survey found that the average cost of filing a patent in the United States or Japan is around 20 per cent cheaper than the EPO. This is because, although the attorney fees are much lower in Europe, the official patent office fees, at DM9,900, are at least three times as high.

Another major item of expenditure for European patents that is not shared by Japan and the United States is translation costs. Patent applications can be submitted in one of the three EPO official languages, namely English, French or German, with the summarized claims being translated into the other two languages on publication.

But EPO member states insist that any EPO patent given protection in their country must be translated in full into the national language. This means that for an average patent, covering eight designated member states, translation costs constitute on average DM15,200, or one-third of the total cost.

The EPO is keen to reduce the costs associated with translation. But doing so requires the political agreement of its member states. Although translations have no legal status, attempts in the past to eliminate their requirement have been resisted by member states, who insist that it is the only way to guarantee their citizens full access to patent information.

The EPO administrative council has highlighted suggestions for cost saving in a discussion document made public last week. The document invites comments from both researchers and industrial representatives on other cost-saving proposals, such as reducing the duplication of work between the EPO and national patent offices, for example by centralizing of some activities such as translation.

Another suggestion would be to devolve responsibility for activities such as searches to the larger national offices. But this is a politically-sensitive issue because of the continuing power struggle between the national and European offices.

Furthermore, any conclusions based on the comments received could take a considerable time to implement. As EPO staff members despairingly note, the conflicting interests of member states have frequently in the past prevented apparently obvious solutions to the EPO's problems from being introduced.

Alison Abbott

\section{Chirac downgrades science in re-shuffle of ministries}

Paris. The incoming government of France's new president, Jacques Chirac, has stunned the country's researchers by abolishing France's independent science ministry. The change ends the prominent political status given to research under France's Socialist president François Mitterrand during his 14-year period of office.

"It's a step backwards of about 20 years for research," said one leading French research official in reaction to news that the administration of Alain Juppé, the new Prime Minister, will fold research into a superministry of "national education, higher education, research and social insertion".

Under the governments of Mitterrand, research either had its own

\section{Bayrou: keen to allay} concerns over CNRS. ministry, or was combined with higher education or with industry. Observers fear that the new arrangements could result in research being neglected because of the enormous day-to-day demands of the school and higher education portfolios.

The nomination of a secretary of state for research has done little to allay such concerns. Unlike ministers and junior ministers, secretaries of state do not routinely attend cabinet meetings, for example.

Moreover, while research was run by a secretary of state under Giscard d'Estaing's presidency during the $1970 \mathrm{~s}$, the post was directly attached to the prime minister. It is now attached to the education ministry.

The lack of a cabinet minister dedicated to research could, in particular, damage France's ability to develop both a national strategy for research, and its international policy, particularly in Brussels, argues Pierre Papon, chairman of the Observatoire de Science et Technologie, and a former head of the Centre National de la Recherche Scientifique (CNRS).

Moreover, the new secretary of state, Elisabeth Dufourcq, 54, is relatively unknown in science policy circles. She is a researcher at INSERM, the national biomedical research agency, a member of the national bioethics advisory committee, and a historian who has published several books on women missionaries.

Observers argue that while the appointment of a secretary of state for research may improve day-to-day management of the research portfolio, Dufourcq lacks the political clout of past research ministers such as François Fillon or JeanPierre Chevènement - who were both career politicians.

Nor will she start her new role with the reputation of the geophysicist Hubert Curien, who, although not a politician by profession, had headed both the French space agency (CNES) and CNRS, and was considered to be more wily than many professional politicians.

Some fear that the lack of such political punch will mean bad news for research, particularly when budget levels need to be negotiated with the powerful finance ministry. "My overall impression [of the new ministerial configuration] is that the political weight of research has been very strongly diminished," says one observer.

Edouard Brezin, the president of CNRS, argues that it is too soon to judge the new government's commitment to research. Although admitting that he would have been "more reassured" by an independent research ministry, he says he "hopes research will be one of the government's priorities."

In contrast, the SNCS, one of the labour unions that represent researchers, criticized the "drowning" of research within the new "superministry", as "a bad omen for the attitude of the new government to research".

While some argue that research is unlikely to face the harsh cuts it experienced when Chirac was prime minister in 1986, few believe he will keep his campaign promise to increase research spending.

They point out that during his election campaign, Chirac stated in an interview with $L a$ Recherche magazine that he favoured a dedicated research ministry, arguing that while the links between research and the universities were important, research had many aspects, and went far beyond the university.

The new minister who will hold ultimate political responsibility for research is François Bayrou, who was also minister of national education in the previous government. Bayrou visited CNRS headquarters last weekend immediately after his nomination, along with Dufourcq, in what is being seen as an attempt to allay concerns over the future of the cash-strapped agency (see Nature 374, 666, 1995). "Research will be at the centre of my preoccupations", he said, adding that he intended to make regular visits to CNRS.

Bayrou emphasized the "tight links" between research and education. He added that CNRS "assumes one of the grand functions of the nation, and is at the heart of one of the grand ministries of the Republic: this is a message of respect, and, I hope, of hope."

Declan Butler 